\title{
Preservation of marine planktonic ciliates: losses and cell shrinkage during fixation
}

\author{
Diane K. Stoecker ${ }^{1}$, Dian J. Gifford ${ }^{2}$, Mary Putt ${ }^{3}$ \\ ${ }^{1}$ Horn Point Environmental Laboratory, PO Box 775, Cambridge, Maryland 21613, USA \\ ${ }^{2}$ Graduate School of Oceanography, University of Rhode Island, Narragansett, Rhode Island 02882, USA \\ ${ }^{3} 713$ Cricklewood Drive, State College, Pennsylvania 16803, USA
}

\begin{abstract}
For enumeration of microzooplankton $(20-200 \mu \mathrm{m}$ size fraction), including planktonic ciliates, water samples are usually fixed and preserved, then concentrated by sedimentation in Utermöhl chambers and examined with an inverted microscope. However, losses of ciliates may occur during fixation and handling, and fixation may shrink cells. Estimates of abundance with several commonly used fixatives were compared in samples from the North Atlantic and subarctic Pacific Oceans and in samples from cultures. Buffered formaldehyde has the advantage that it allows epifluorescence microscopy to be used, but, on average, ciliate counts from the North Atlantic were $56 \%$ higher (95\% Cl 30 to $82 \%$ ) in samples fixed with $10 \%$ acid Lugol's solution than in samples fixed with $2 \%$ formaldehyde. Ciliate counts from the subarctic Pacific were 23 to $49 \%$ higher in samples fixed with 10 or $20 \%$ acid Lugol's solution than in samples fixed with $5 \%$ acid Lugol's solution. Fixation with 10 or $20 \%$ acid Lugol's solution results in significantly higher cell counts than fixation with formaldehyde or dilute acid Lugol's solution, but shrinks cells severely and often distorts their morphology. Bouin's solution yields cell counts that are usually similar to those with $10 \%$ acid Lugol's solution, but with less shrinkage. No single fixation method is ideal for all purposes; fixative-specific and assemblage- or taxon-specific correction factors are necessary for accurate estimates of cell numbers and cell volumes/biomass.
\end{abstract}

KEY WORDS: Microzooplankton · Ciliates · Oligotrichs · Fixation · Shrinkage $\cdot$ Cell losses · Inverted microscope technique

\section{INTRODUCTION}

Ciliates are an important component of the protistan plankton in marine, estuarine and fresh waters (e.g. Beers \& Stewart 1969, Rassoulzadegan \& Gostan 1976, Pace \& Orcutt 1981, Smetacek 1981, Sorokin 1981, Revelante \& Gilmartin 1983). In open waters, the ciliate assemblage is usually dominated by non-loricate, oligotrichous taxa (Sorokin 1991). Planktonic ciliates are important as consumers of pico- and nanoplankton (Rassoulzadegan et al. 1988). Autotrophic and mixotrophic ciliates also contribute to primary production in the microplankton size fraction (Jonsson 1987, Stoecker et al. 1987a). Planktonic ciliates are, at times, important components of the diet of copepods and other macrozooplankton (Stoecker \& Capuzzo 1990, Gifford 1993b).

Microplankton, including $\geq 20 \mu \mathrm{m}$ ciliates, are usually collected as part of whole water samples, fixed and pre- served, concentrated by sedimentation, and then enumerated using the inverted microscope method (Hasle 1978). Filtration and staining techniques suitable for nanoplankton ( $<20 \mu \mathrm{m}$ protists) (reviewed by Sherr \& Sherr 1993) are generally not suitable for enumerating the larger microzooplankton that typically occur at lower densities than nanoplankton in open, coastal waters and oceanic waters. An exception is the Quantitive Protargol Technique (QPS) which has been used to enumerate and identify both nano- and microplanktonic ciliates and dinoflagellates from coastal waters (Montagnes \& Lynn 1987, Bockstahler \& Coats 1993).

A number of fixatives/preservatives have been used in conjunction with the inverted microscope technique to enumerate microplankton in seawater samples, including dilute formaldehyde (Beers 1978, Dale \& Burkill 1982, Stoecker et al. 1987a), a modified Bouin's solution (Dolan \& Coats 1990), and various concentra- 
tions of acid Lugol's solution (Gifford 1988, 1993a, Sherr \& Sherr 1993). Although dilute acid Lugol's solution is recommended for enumeration of flagellates (Throndsen 1978) and has been used to fix and preserve ciliates (Revelante \& Gilmartin 1983, Putt \& Stoecker 1989, Ohman \& Snyder 1991, Jerome et al. 1993) use of higher concentrations may reduce ciliate losses (Gifford 1993a, b). Live counting of ciliates often results in significantly higher estimates of ciliate abundance than does counting of preserved samples (Sorokin 1981). For example, Dale \& Burkill (1982) found that live counting of ciliates from coastal waters often resulted in up to $20 \%$ higher estimates of abundance than did counting of samples preserved with $0.4 \%$ (final conc.) neutral formaldehyde. This raises the question of the importance of cell losses during fixation and whether fixation method influences estimates of abundance in microzooplankton assemblages.

The biomass of ciliate assemblages is typically estimated from numerical abundance and cell size using volume:carbon conversion factors. Shrinkage, caused by fixation and preservation may affect estimates of cell biomass based on measurements of cell volume (Choi \& Stoecker 1989, Putt \& Stoecker 1989, Ohman \& Synder 1991, Jerome et al. 1993). Field and laboratory experiments were done to address the question of how fixation procedure affects estimates of ciliate abundance and biomass. Experiments were done at 2 oceanic stations in order to compare the effects of various fixatives on estimates of cell number in natural microplankton assemblages. Because it is difficult to compare fixation losses for individual species or to compare changes in cell volume in natural assemblages, experiments on fixation and preservation of laboratory cultures representative of the Oligotrichidia (Strombidium) and the Choreotrichida (Strobilidium, non-loricate and Favella, loricate) were also performed.

\section{METHODS}

Fixation experiments with natural assemblages. In the North Atlantic experiment, water samples were collected with Niskin bottles from 4 depths in the upper water column ( $z=0$ to $34 \mathrm{~m}$ ) on 3 dates during late spring 1989. Sampling was done from the RV 'Atlantis II' in the vicinity of $47^{\circ} \mathrm{N}, 18^{\circ} \mathrm{W}$ as part of the JGOFS North Atlantic Bloom Experiment (Sieracki et al. 1993). Whole water samples (950 to $990 \mathrm{ml}$, depending on fixative) from each Niskin bottle were drained through silicon tubing into 3 jars containing different fixatives: $2 \%$ formaldehyde buffered with hexamethylamine (Throndsen 1978), 10\% acid Lugol's solution (Throndsen 1978), and 5\% Bouin's solution (stock solution from Sigma Diagnostics) (all final conc., v/v).
In the oceanic subarctic Pacific experiment, seawater was collected from the middle of the mixed layer $(z=$ $35 \mathrm{~m}$ ) at Stn $\mathrm{P}$ near $50^{\circ} \mathrm{N}, 145^{\circ} \mathrm{W}$. A teflon-lined $30 \mathrm{l}$ Go-Flo bottle was used to sample from the RV 'Thomas G. Thompson' as part of the SUPER (SUbarctic Pacific Ecocystem Research) program. Whole water samples (1600 to $1900 \mathrm{ml}$, depending on fixative concentration) were drained through silicon tubing into jars containing 3 concentrations of acid Lugol's solution: $5 \%, 10 \%$ and $20 \%$ (final v/v).

Several months later, $100 \mathrm{ml}$ subsamples were concentrated by sedimentation using Utermöhl chambers and examined with an inverted microscope (Hasle 1978). All aloricate ciliates in the settling chambers were enumerated at $200 \times$ or $250 \times$ magnification. Loricate ciliates (tintinnids) were absent from the North Atlantic samples and were present, but rare, in the subarctic Pacific samples. Tintinnids are not included in the total counts. In the North Atlantic samples, only total counts of aloricate choreotrichs and oligotrichs were made. In the samples from the subarctic Pacific, the aloricate ciliates were categorized on the basis of geometry as spheres or cones; oral membranelles and tail structures were not included in the estimates of cell geometry. The large mixotroph Laboea strobila was enumerated separately from other cone-shaped ciliates. Ciliate densities were corrected for the volume of fixative in each sample and expressed as cells $\mathrm{l}^{-1}$.

Fixation experiments with cultured ciliates. Fixation of ciliate cultures with $2 \%, 5 \%$ and $10 \%$ acid Lugol's solution, $2 \%$ buffered formaldehyde, and $5 \%$ Bouin's solution were compared in the laboratory to confirm and expand the results of the comparative fixation experiments done with natural assemblages. Three cultures representative of important ciliate taxa in the oceans were used: Strombidium capitatum (an oligotrich), Strobilidium spiralis (an aloricate choreotrich) and a tintinnid, Favella sp. (a loricate choreotrich). Culture methods are described in Stoecker et al. (1987b). The 3 cultures were mixed together and triplicate $\sim 150 \mathrm{ml}$ samples were preserved in each fixative. Samples were stored for several weeks before $100 \mathrm{ml}$ subsamples were settled in Utermöhl chambers and each species enumerated using the inverted microscope technique.

To compare cell volumes, 30 to 31 cells of each species from each replicate were measured with a calibrated ocular micrometer. Cell volume was estimated using an ellipsoid approximation of cell shape for all 3 species. Oral membranelles and tail structures were not included in the estimates of cell volume. Only the cell inside the lorica of Favella sp. was measured.

Statistical analyses. Two-way analysis of variance was done using SAS. All tests of significance were performed at the $\mathrm{p}=0.05$ level. A Bonferroni (LSD) cor- 
rection to the significance level was used when multiple comparisons were made (Kleinbaum et al. 1988).

For the North Atlantic data it was assumed that ciliate counts for any 2 preservatives are related in a linear fashion. Replicate counts were not made, however it seems unlikely that the standard errors of the dependent variables are constant over the range of observed cell densities (156 to $9489 \mathrm{l}^{-1}$ ). Thus, ordinary least squares regression is inappropriate. Instead, a quasi-likelihood approach (McCullagh \& Nelder 1991) was employed. Using this approach, we fit a linear relationship and also included the assumption that the variance of the dependent variable is proportional to its mean. Parameter, variance and proportionality constant estimates were computed using STATA (Hilbe 1993). Approximate $95 \%$ confidence intervals for the mean were based on large sample normal approximations. Negative estimates of the intercept were truncated to zero.

\section{RESULTS}

In the North Atlantic samples, the ciliate abundance estimates from water fixed with $10 \%$ acid Lugol's solution were significantly higher $(p=0.006)$ than those of water fixed with $2 \%$ buffered formaldehyde (Fig. 1A). On average, estimates for samples preserved with $10 \%$ acid Lugol's solution were $56 \%(95 \% \mathrm{CI}$ of 30 to $82 \%$ ) higher than the formaldehyde based estimate for the same samples (Fig. 1A). The estimates of ciliate abundance in samples preserved with acid Lugol's solution were, on average, about $7 \%$ higher than the corresponding estimates for samples preserved with Bouin's solution, but the differences between samples were not significant (Fig. 1B).

The fixation experiment from the subarctic Pacific indicates that the concentration of acid Lugol's solution employed has a significant effect on abundance estimates (Table 1). Abundance estimates from samples fixed with $10 \%$ acid Lugol's solution were significantly higher than estimates from corresponding samples fixed with $5 \%$ acid Lugol's solution. Although the average abundance estimates for conical ciliates were higher in the treatment with $20 \%$ rather than $10 \%$ acid Lugol's solution, the estimates of total ciliate abundance were not significantly different between these 2 treatments. The interaction between ciliate category (cone, sphere or Laboea) and percent acid Lugol's solution was not statistically significant (Table 1). However the average abundance of Laboea sp. and other ciliates with a conical morphology was greater with the higher concentrations of fixative. Differences between species

Table 1. Abundances of 3 morphological types of ciliates (cells $1^{-1}$ ) in samples from the sub-arctic Pacific preserved with $5 \%$, $10 \%$, and $20 \%$ acid Lugol's solution (L). Abundances were corrected for the volume of fixative. Means of 3 replicates (SD in parentheses). ns: non-significant $(p<0.05)$

\begin{tabular}{|c|c|c|c|c|}
\hline & $5 \% \mathrm{~L}$ & \multicolumn{2}{|c|}{$10 \% \mathrm{~L}$} & $20 \% \mathrm{~L}$ \\
\hline Laboea strobila & $204(22)$ & \multicolumn{2}{|c|}{$263(39)$} & $304(79)$ \\
\hline Conical morphology ${ }^{a}$ & $442(74)$ & \multicolumn{2}{|c|}{$556(80)$} & $654(170)$ \\
\hline Spherical morphology & Y $400(104)$ & \multicolumn{2}{|c|}{$544(51)$} & $492(108)$ \\
\hline \multicolumn{5}{|l|}{ 2-way ANOVA } \\
\hline Source of variation $M$ & Mean square & $\mathrm{df}$ & \multicolumn{2}{|c|}{$F$ value } \\
\hline$\%$ Acid Lugol's & 45306 & 2 & 5.52 & $p<0.05$ \\
\hline Morphological type & 210983 & 2 & 25.69 & $p<0.001$ \\
\hline Interaction & 6093 & 4 & 0.74 & ns \\
\hline Error & 8213 & 18 & & \\
\hline \multicolumn{5}{|c|}{ A priori comparisons (LSM) } \\
\hline $5 \%$ L vs $10 \% \mathrm{~L}$ & $\mathrm{p}<0.05$ & & & \\
\hline $10 \% \mathrm{~L}$ vs $20 \% \mathrm{~L}$ & ns & & & \\
\hline${ }^{\mathrm{N}}$ Not including Laboea & & & & \\
\hline
\end{tabular}

Fig. 1. Relationship of abundance estimates of planktonic ciliates (cells $\mathrm{l}^{-1}$ ) for samples from surface waters of the North Atlantic fixed and preserved with (A) $10 \%$ acid Lugol's solution versus $2 \%$ buffered formaldehyde and (B) $5 \%$ Bouin's solution. The linear relationship was estimated using the model $Y=b_{0}+b_{1} X$, where $X$ is the estimate with $2 \%$ formaldehdye (A) or $5 \%$ Bouin's solution (B) and $Y$ is the estimate with $10 \%$ acid Lugol's solution. Average abundance with $10 \%$ Lugol's predicted from the estimated slope $\left(b_{1}\right)$ and intercept $\left(b_{0}\right)(-)$ with $95 \%$ confidence interval (-.---). The predicted line which would arise if $b_{0}=0$ and $b_{1}=1$ $(----)$ is shown in (A). Parameter estimates (95\% CI): Lugol's on formaldehyde (A) $b_{0}=57$ $(0,318) ; b_{1}=1.56(1.30,1.82)$, Lugol's on Bouin's $b_{0}=-8(0,499), b_{1}=1.07(0.76,1.37)$
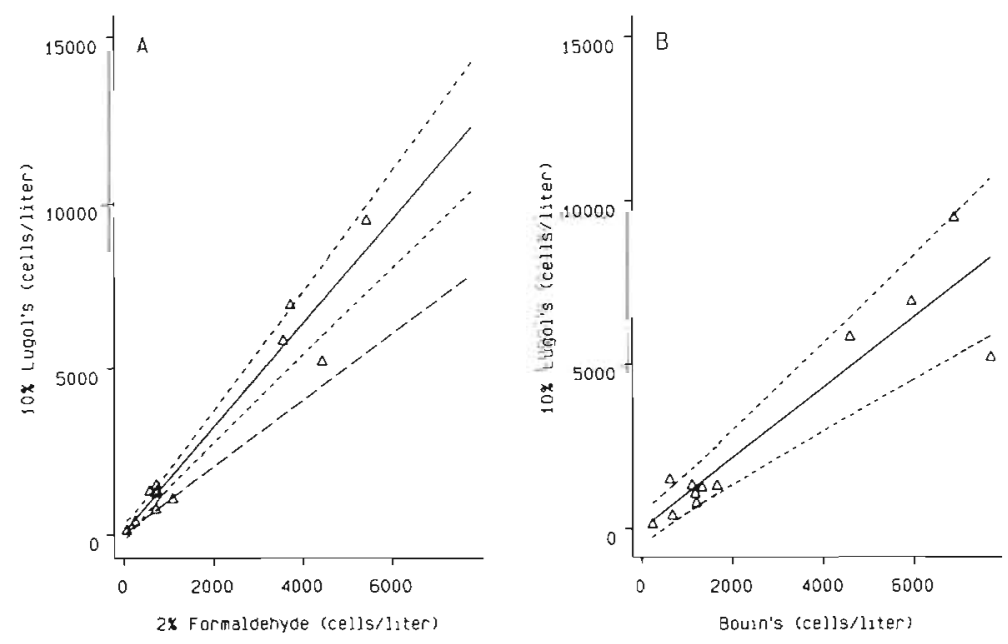
may have existed but may have been below the 'limit of detection' for this experiment.

In the laboratory experiments, interactions between species and fixation treatment were significant for both abundance estimates (Table 2) and cell size (Table 3). Although abundances of all 3 species varied with fixation treatment, betweentreatment differences were only significant in Strombidium capitatum (Table 2). For this oligotrich, the estimates with $2 \%$ buffered formaldehyde were significantly lower than the estimates with $5 \%$ or $10 \%$ acid Lugol's solution (Table 2). For example, the estimate of $S$. capitatum cell density with $2 \%$ formaldehyde was only $64 \%$ of the estimate with $10 \%$ acid Lugol's fixation.

Fixation method influenced cell size in all 3 species (Table 3 ). Cell volumes in the $10 \%$ acid Lugol's treatment were significantly lower than cell volumes with the $2 \%$ acid
Table 2. Abundances (cells $100 \mathrm{ml}^{-1}$ ) of cultured ciliates preserved with $2 \%, 5 \%$, $10 \%$ acid Lugol's solution (L), $2 \%$ buffered formaldehyde $(\mathrm{F})$ and $5 \%$ Bouin's solution (B). Means of 3 replicates (SD in parentheses). ns: non-significant $(p<0.05)$

\begin{tabular}{|c|c|c|c|c|c|}
\hline & $2 \% \mathrm{~L}$ & $5 \% \mathrm{~L}$ & $10 \% \mathrm{~L}$ & $2 \% \mathrm{~F}$ & $5 \% \mathrm{~B}$ \\
\hline Strobilidium spiralis & $151(5)$ & $140(4)$ & $167(9)$ & $138(14)$ & $165(9)$ \\
\hline Favella sp. & $288(12$ & $264(11)$ & $277(20)$ & $246(11)$ & $234(24)$ \\
\hline Strombidium capitatum & $227(15$ & $272(32)$ & $300(39)$ & $193(7)$ & $251(23)$ \\
\hline \multicolumn{6}{|l|}{ 2-way ANOVA } \\
\hline Source of variation & \multicolumn{2}{|c|}{ Mean square } & df & \multicolumn{2}{|c|}{$F$ value } \\
\hline Preservative & \multicolumn{2}{|c|}{3549} & 4 & \multicolumn{2}{|l|}{6.87} \\
\hline Species & \multicolumn{2}{|c|}{54983} & 2 & \multicolumn{2}{|l|}{106.48} \\
\hline Interaction & \multicolumn{2}{|c|}{1597} & 8 & \multirow[t]{2}{*}{3.09} & \multirow[t]{2}{*}{$\mathrm{p}<0.05$} \\
\hline Error & & 16 & 30 & & \\
\hline \multicolumn{6}{|c|}{ A priori comparisons (LSM) } \\
\hline$S$. & spiralis & Favella sp. & S. Capitat & $u m$ & \\
\hline $2 \% \mathrm{~L}$ vs $10 \% \mathrm{~L}$ & ns & ns & ns & & \\
\hline $2 \%$ L vs $5 \% \mathrm{~L}$ & ns & ns & ns & & \\
\hline $5 \% \mathrm{~L}$ vs $10 \% \mathrm{~L}$ & ns & ns & ns & & \\
\hline $2 \%$ F vs $2 \% \mathrm{~L}$ & ns & ns & ns & & \\
\hline $2 \% \mathrm{~F}$ vs $5 \% \mathrm{~L}$ & ns & ns & $\mathrm{p}<0.05$ & & \\
\hline $2 \%$ F vs $10 \% \mathrm{~L}$ & ns & ns & $\mathrm{p}<0.05$ & & \\
\hline $5 \%$ B vs $10 \% \mathrm{~L}$ & ns & ns & ns & & \\
\hline
\end{tabular}

Table 3. Mean cell volume $\left(\mu \mathrm{m}^{3} \times 10^{6}\right)$ of cultured ciliates preserved with $2 \%, 5 \%, 10 \%$ acid Lugol's solution (L), $2 \%$ buffered formaldehyde (F) and 5\% Bouin's solution (B). Means of 3 replicates (SD in parenthesesì, except for $2 \% \mathrm{~L}$ means of 2 replicates (range in parentheses)

\begin{tabular}{|c|c|c|c|c|c|}
\hline & $2 \% \mathrm{~L}$ & $5 \% \mathrm{~L}$ & $10 \% \mathrm{~L}$ & $2 \% \mathrm{~F}$ & $5 \% \mathrm{~B}$ \\
\hline Strobilidium spiralis & $45.0(40.1-49.9)$ & $40.2(3.6)$ & $35.8(1.9)$ & $60.4(2.4)$ & $38.2(1.8)$ \\
\hline Favella sp. & $73.5(70.1-76.9)$ & $74.4(2.1)$ & $61.3(3.6)$ & $108.9(0.6)$ & $76.2(8.5)$ \\
\hline Strombidium capitatum & $47.3(42.6-52.0)$ & $43.2(1.6)$ & $31.4(3.5)$ & $77.1(6.3)$ & $45.8(5.4)$ \\
\hline \multicolumn{6}{|l|}{ 2-way ANOVA } \\
\hline Source of variation & Mean square & $\mathrm{df}$ & $F$ value & & \\
\hline Preservative & $1948 \times 10^{6}$ & 4 & 102.25 & & \\
\hline Species & $4860 \times 10^{6}$ & 2 & 255.15 & & \\
\hline Interaction & $71 \times 10^{6}$ & 8 & 3.71 & $p<0.05$ & \\
\hline Error & $19 \times 10^{6}$ & 27 & & & \\
\hline \multicolumn{6}{|c|}{ A priori comparisons (LSM) } \\
\hline & S. spiralis & Favella sp. & S. capitatum & & \\
\hline $2 \% \mathrm{~L}$ vs $10 \% \mathrm{~L}$ & ns & $p<0.05$ & $p<0.05$ & & \\
\hline $2 \% \mathrm{~L}$ vs $5 \% \mathrm{~L}$ & ns & ns & ns & & \\
\hline $5 \% \mathrm{~L}$ vs $10 \% \mathrm{~L}$ & ns & $p<0.05$ & $\mathrm{p}<0.05$ & & \\
\hline $2 \%$ Fvs $2 \% \mathrm{~L}$ & $p<0.05$ & $p<0.05$ & $p<0.05$ & & \\
\hline $2 \%$ F v $5 \% \mathrm{~L}$ & $p<0.05$ & $p<0.05$ & $p<0.05$ & & \\
\hline $2 \%$ F vs $10 \% \mathrm{~L}$ & $p<0.05$ & $p<0.05$ & $p<0.05$ & & \\
\hline $5 \%$ B vs $10 \% \mathrm{~L}$ & ns & $p<0.05$ & $p<0.05$ & & \\
\hline
\end{tabular}


Lugol's treatment for all 3 species. For Strombidium capitatum and Favella sp., cell volumes with $10 \%$ acid Lugol's solution were significantly lower than with $5 \%$ acid Lugol's solution. For all 3 species, cell volumes with $2 \%, 5 \%$ and $10 \%$ acid Lugol's solution were significantly lower than with $2 \%$ buffered formaldehyde. For example, the cell volume of $S$. capitatum preserved in $2 \%$ buffered formaldehyde was $2.45 \times$ the volume of similar cells preserved in $10 \%$ acid Lugol's solution. For Favella sp. and $S$. capitatum, but not $S$. spiralis, volumes of cells preserved with $5 \%$ Bouin's solution were significantly higher than those preserved with $10 \%$ acid Lugol's solution. In all cases, volumes of cells preserved with $2 \%$ formaldehyde were significantly higher than those preserved with $5 \%$ Bouin's solution.

\section{DISCUSSION}

Method of fixation can influence estimates of ciliate numerical abundance significantly (Pace \& Orcutt 1981, Revelante \& Gilmartin 1983; R. Leakey, P. Burkhill \& M. Sleigh summarized in Rassoulzadegan 1991). The combined results of our field and laboratory experiments indicate that higher cell counts are obtained in either strong ( 10 or $20 \%$ ) acid Lugol's solution or Bouin's solution than in $2 \%$ acid Lugol's solution or $2 \%$ formaldehyde. Higher non-loricate ciliate densities in samples fixed with $1 \%$ acid Lugol's (final conc.) than in samples fixed with formaldehyde have been reported previously by Pace \& Orcutt (1981) and Revelante \& Gilmartin (1983). However, our data indicate that counts of oligotrichs are significantly higher in strong $(\geq 10 \%)$ than in the dilute $(\leq 2 \%)$ acid Lugol's solution. Low concentrations of acid Lugol's solution (usually 0.5 to $2 \%$ ) have traditionally been used to preserve microplankton samples (Sherr \& Sherr 1993) although Gifford (1993a) recommends $10 \%$ for ciliates. The data in Table 1 suggest that for certain ciliates (Laboea and other ciliates with a conical morphology) slightly higher counts may be obtained with $20 \%$ than with $10 \%$ acid Lugol's solution. However, with $20 \%$ acid Lugol's solution, ciliates may be difficult to identify and size because of severe shrinkage, distortion of morphology and dark coloration. The iodine color can be bleached with sodium thiosulfate (E. Sherr \& B. Sherr summarized in Rassoulzadegan 1991, Sherr \& Sherr 1993), laundry bleach (Gifford pers. obs.) or light (Gifford pers. obs.).

For cells preserved with $2 \%$ buffered formaldehyde, abundance estimates of oligotrichs were on average 63 to $64 \%$ of those obtained for cells preserved with $10 \%$ acid Lugol's solution (Fig. 1A, Table 2). Although cell losses are significant with this fixative, formaldehyde has the advantage that it can be used in conjunc- tion with epifluorescence microscopy, and thus plastidic and non-plastidic cells can be distinguished (Stoecker et al. 1987a).

Because estimates of ciliate abundance from fixed samples were not compared to live counts, we do not know the accuracy of our estimates. However, Dale \& Burkill's (1982) reported loss factors of up to $20 \%$ with dilute buffered formaldehyde (compared to live counts) and our estimated loss factor of 30 to $40 \%$ (compared to $10 \%$ acid Lugol's) with buffered formaldehyde suggest that the estimates obtained with 10 or $20 \%$ acid Lugol's solution or $5 \%$ Bouin's are close to maximum. However, our experiment with cultures of ciliates demonstrated that cell losses can be taxonspecific (Table 2). It is thus possible that some species are not fixed and preserved quantitatively with either strong acid Lugol's or Bouin's solutions.

Type of fixative as well as fixative concentration and ciliate taxa also influence biomass estimates through their effect on post-fixation cell volume (Table 3 ). Similar effects of fixation on ciliate cell volume have been reported by Choi \& Stoecker (1989), Putt \& Stoecker (1989), Ohman \& Snyder (1991) and Jerome et al. (1993). Volume to carbon conversion factors for preserved planktonic ciliates, such as those of Putt \& Stoecker (1989) and Ohman \& Snyder (1991) are fixative- and probably taxon-specific. For example, if the volume to carbon conversion factor of $0.14 \mathrm{pg} \mathrm{C}_{\mathrm{mm}}^{-3}$ for oligotrichs preserved in $2 \%$ buffered formaldehyde (Putt \& Stoecker 1989) is applied to oligotrichs preserved with $2 \%$ acid Lugol's solution or $5 \%$ Bouin's solution, biomass is probably underestimated by about $40 \%$. If the same ciliates are fixed with $10 \%$ acid Lugol's solution, biomass is probably underestimated by about $59 \%$ with the formaldehyde conversion factor.

Fixation procedures can have a large effect on the estimation of planktonic ciliate abundance and biomass (Sime-Ngando et al. 1990, Ohman \& Snyder 1991, Sime-Ngando \& Groliere 1991, Jerome et al. 1993). Failure to account for losses during fixation can result in an underestimation of ciliate numbers and biomass (Fig. 1A, Tables $1 \& 2$ ). Failure to adjust volume:carbon conversion factors for cell shrinkage (Table 3) may underestimate ciliate biomass by $>40 \%$. Because some taxa appear to be more sensitive to these effects than others (Sime-Ngando \& Grolière 1991, Jerome et al. 1993) the taxonomic composition of the ciliate assemblage probably affects the accuracy of estimates of ciliate abundance and biomass.

Correcting for cell losses in samples preserved in dilute acid Lugol's solution or $2 \%$ formaldehyde based on our data may not be appropriate for all samples, in part because of the taxon-specific effects of the different fixatives. Other factors may influence cell losses 
and cell shrinkage as well. Losses may occur prior to fixation due to the mechanics of collection or manipulation of the sample (Gifford 1985). Osmotic affects (Jerome et al. 1993), due to the salinity, as well as the feeding history of cells (Choi \& Stoecker 1989) may influence preservation and shrinkage. Cell losses in liquid samples may increase with storage time (Sherr \& Sherr 1993), although this does not appear to be the case for marine ciliates preserved in acid Lugol's solution (Ohman \& Snyder 1991, Gifford unpubl. data). For all of the above reasons, carbon:volume factors and factors correcting for cell loss and shrinkage should not be used indiscriminately. Individual investigators must check or derive correction factors for the particular microplankton assemblages and environmental conditions which apply in their own research. Further comparisons of numerical and biomass estimates obtained with different fixation and preservation methods and live techniques are needed before correction factors can be recommended for routine use.

Acknowledgements. This research was partially supported by NSF grants OCE-88-17399, OCE-86-13892 and DPP-88-16668. We thank P. G. Verity and M. E. Sieracki and the USJGOFS program for the help in obtaining the North Atlantic samples, the SUPER program for assistance in the subarctic Pacific and A. E. Michaels for assistance in the culturing and enumeration of ciliate samples. Critical reviews by F. Rassoulzadegan and 2 anonymous readers are appreciated.

\section{LITERATURE CITED}

Beers, J. R. (1978). About microzooplankton. In: Sournia, A. (ed.) Phytoplankton manual. UNESCO, Paris, p. 288-296

Beers, J. R., Stewart, G. L. (1969). Microzooplankton and its abundance relative to larger zooplankton and other seston components. Mar. Biol. 4: 182-189

Bockstahler, K. R., Coats, D. W. (1993). Grazing of the mixotrophic dinoflagellate Gymnodinium sanguineum Hirasaka on ciliate populations of Chesapeake Bay. Mar. Biol. 116: $477-487$

Choi, J. W., Stoecker, D. K. (1989). Effects of fixation on cell volume of marine planktonic protozoa. Appl. environ. Microbiol. 55: 1761-1765

Dale, T., Burkill P. H. (1982). 'Live counting' - a quick and simple technique for enumerating pelagic ciliates. Annls Inst. océanogr., Paris 58(S): 267-276

Dolan, J. R., Coats, D. W. (1990). Seasonal abundance of planktonic ciliates and microflagellates in mesohaline Chesapeake Bay waters. Estuar. coast. Shelf Sci. 31: 157-175

Gifford, D. J. (1985). Laboratory culture of marine planktonic oligotrichs (Ciliophora, Oligotrichida). Mar Ecol. Prog Ser. 23: 257-267

Gifford, D. J. (1988). Impact of grazing by microzooplankton in the northwest arm of Halifax Habour, Nova Scotia. Mar. Ecol. Prog. Ser. 47: 249-258

Gifford, D. J. (1993a). Consumption of protozoa by copepods feeding in natural microplankton assemblages. In: Kemp, P. F., Sherr, B. F., Sherr, E. B., Cole, J. J. (eds.) Handbook of methods in aquatic microbial ecology. Lewis Publishers, Boca Raton, p. 723-729
Gifford, D. J. (1993b). Protozoa in the diets of Neocalanus spp. in the oceanic subarctic Pacific Ocean. Prog. Oceanogr. 32: $223-237$

Hasle, G. R. (1978). The inverted-microscope method. In: Sournia, A. (ed.) Phytoplankton manual. UNESCO, Paris, p. $88-96$

Hilbe, J. (1993). Generalized linear models. Stat. techn. Bull. 11: $20-28$

Jerome, C. A., Montagnes, D. J. S., Taylor, F. J. R. (1993). The effect of the quantitive protargol stain and Lugol's and Bouin's fixatives on cell size: a more accurate estimate of ciliate species biomass. J. euk. Microbiol, 40: 254-259

Jonsson, P. R. (1987) Photosynthetic assimilation of inorganic carbon in marine oligotrich ciliates (Ciliophora, Oligotrichina). Mar. microb. Food Webs 2: 55-68

Kleinbaum, D. G., Kupper, L. L., Muller, K. E. (1988). Applied regression analysis and other multivariate methods. PWSKent Publishing Co., Boston

McCullagh, P., Nelder, J. A. (1991). Generalized linear models. Monographs on statistics and applied probability, 37. Chapman and Hall, New York

Montagnes, D. J. S., Lynn, D. H. (1987). A quantitative protargol stain (QPS) for ciliates: method description and test of its quantitative nature. Mar. microb. Food Webs 2: $83-93$

Ohman, M. D., Snyder, R. A. (1991). Growth kinetics of the omnivorous oligotrich ciliate Strombidium $\mathrm{sp}$. Limnol. Oceanogr. 36: 922-935

Pace, M. L.., Orcutt, J. D. Jr (1981). The relative importance of protozoans, rotifers, and crustaceans in a freshwater zooplankton community. Limnol Oceanogr. 26: 822-831

Putt, M., Stoecker, D. K. (1989). An experimentally determined carbon-volume ratio for marine oligotrichous ciliates from estuarine and coastal waters. Limnol. Oceanogr. 34: $1097-1103$

Rassoulzadegan, F. (1991) Methods for the study of marine microzooplankton - Session summary. In: Reid, P. C, Turley, C. M., Burkill, P. H. (eds.) Protozoa and their role in marine processes. Springer-Verlag, Berlin, p. 39-57

Rassoulzadegan, F., Gostan, J. (1976). Répartition des ciliés pélagiques dans les eaux de Villefranche-sur-Mer. Remarques sur la dispersion du microzooplankton en mer et à l'intérieur des échantillons dénombrés par la méthode d'Utermöhl. Annls Inst. océanogr., Paris 52: 175-188

Rassoulzadegan, F., Laval-Peuto, M., Sheldon, R. W. (1988). Partitioning of the food ration of marine ciliates between pico- and nanoplankton. Hydrobiologia 159: 75-88

Revelante, N. Gilmartin, M. (1983). Microzooplankton distribution in the Northern Adriatic Sea with emphasis on the relative abundance of ciliated protozoans. Oceanologica Acta 6: 407-415

Sherr, E. B., Sherr, B. F. (1993). Preservation and storage of samples for enumeration of heterotrophic protists. In: Kemp, P. F., Sherr, B. F., Sherr, E. B., Cole, J. J. (eds.) Handbook of methods in aquatic microbial ecology. Lewis Publishers, Boca Raton, p. 207-212

Sieracki, M. E., Verity, P. G., Stoecker, D. K. (1993). Plankton community response to silicate and nitrate depletion at $47^{\circ}$ during the 1989 North Atlantic spring bloom. Deep Sea Res. 40: 213-225

Sime-Ngando, T., Grolière, C. A. (1991). Effets quantitatifs des Fixateurs sur la Conservation des Ciliés Planctoniques d'Eau Douce. Arch. Protistenkd. 140: 109-120

Sime-Ngando, T., Hartmann, H. J., Grolière, C. A. (1990). Rapid quantification of planktonic ciliates: comparison of improved live counting with other methods. Appl. environ. Microbiol 56: 2234-2242 
Smetacek, V. (1981). The annual cycle of protozooplankton in the Kiel Bight. Mar. Biol. 63: 1-11

Sorokin, Y. I. (1981). Microheterotrophic organisms in marine ecosystems. In: Longhurst, A. R. (ed.). Analysis of marine ecosystems. Academic Press, New York, p. 293-341

Stoecker, D. K. Capuzzo, J. M. (1980). Predation on Protozoa: its importance to zooplankton. J. Plankton Res. 12: $891-908$

This article was submitted to the editor
Stoecker, D. K., Michaels, A. E., Davis, L. H. (1987a). Large proportion of marine planktonic ciliates found to contain functional chloroplasts. Nature 326: 790-792

Stoecker, D. K., Verity, P. G., Michaels, A. E., Davis, L. H (1987b). Feeding by larval and post-larval ctenophores on microzooplankton. J. Plankton Res. 9: 667-683

Throndsen, J. (1978). Preservation and storage. In: Sournia, A (ed.) Phytoplankton manual. UNESCO, Paris, p. 69-74

Manuscript first received: December 12, 1993

Revised version accepted: April 22, 1994 